\title{
Expérience "deux couleurs" dans le magnésium. Excitation et couplage d'états autoionisants par des sources UV
}

\author{
N. Karapanagioti, Y.L. Shao, O. Faucher, D. Charalambidis, H. Bachau* et E. Cormier* \\ Université de Crète, Fondation pour la Recherche et la Technologie-Grèce, Institut de la \\ Structure Electronique et des Lasers, Box 1527, 71110 Heraklion, Crète, Grèce \\ * Laboratoire de Collisions Atomiques, UPR 260 du CNRS, 351 Cours de la Libération, \\ 33405 Talence, France
}

\begin{abstract}
We study double-resonance processes in Magnesium. One laser is used to "pump" the $3 p^{2}$ resonance through two-photon absorption from the $3 \mathrm{~s}^{2}$ fundamental state of $\mathrm{Mg}$. A second laser couples the $3 \mathrm{p}^{2} \mathrm{l}_{\mathrm{S}}$ resonance to the $3 \mathrm{p} 3 \mathrm{~d}$ 1po narrow autoionizing state. In the experiment the ionization rate is measured in two different situations; with a fixed frequency for the pumping (coupling) laser and varying the frequency of the coupling (pumping) laser. In agreement with the experimental findings, a theoretical study shows that, for particular frequencies of the laser fields, a situation of coherent trapping occurs with a partial stabilization of the system.
\end{abstract}

L'ionisation multiphotonique est un moyen efficace pour l'étude de la structure atomique et plus particulièrement pour les états électroniques de symétrie telle qu'il est impossibie de les exciter par absorption d'un photon. $C^{\prime}$ est le cas des états pairs des atomes alcalino-terreux. Le cas des états autoionisants (situés aux dessus du premier seuil d'ionisation et qui s'autoionisent via l'interaction entre les électrons) est particulièrement intéressant car ces états jouent un rôle important dans l'ionisation multiple et dans les mécanismes d'amplification du rayonnement. Le couplage d'étars autoionisants par des sources lasers intenses met en jeu des couplages dipolaires qui peuvent être du même ordre de grandeur que les corrélations électroniques. L'étude de ces systèmes est un enjeu pour les théoriciens puisqu'il faut développer une approche qui pernet à la fois la description de la structure électronique du système et l'étude dynamique de l'interaction avec le rayonnement. Ces problèmes, ajoutés aux difficultés de mise en oeuvte expérimentale, expliquent pourquoi la plupart des travaux théoriques consacrés au sujet sont basés sur des modèles. 